Отримано: 26 лютого 2018 р.

Прорецензовано: 15 березня 2018 р.

Прийнято до друку: 19 березня 2018 р.

e-mail: sevschool@yandex.ua

DOI: $10.25264 / 2519-2558-2018-1(69) / 2-139-143$
Natalia Samoylenko. Language assessment: impact on teaching and learning cycle. Hayкові записки Наиіонального університету «Острозька академія»: серія «Філологія». Острог : Вид-во НаУОА, 2018. Вип. 1(69), ч. 2, березень. С. 139-143.

Natalia Samoylenko,

Sevastopol State University, Sevastopol

\title{
LANGUAGE ASSESSMENT: IMPACT ON TEACHING AND LEARNING CYCLE
}

The article reveals factors that have influenced the foreign language assessment. The types of assessments with using ICT, the Language Portfolio are analyzed. The author describes the students' language portfolio examples. It is proved the efficiency of its implementation in higher pedagogical educational institutions teaching practice.

Key words: assessment, assessment mode and tools, digital story, Language Portfolio (LP), language learning achievement, higher pedagogical educational institution.

Самойленко Наталія Борисівна,

Севастопольский державний університет, м. Севастополь

\section{ОЦІНЮВАННЯ ВОЛОДІННЯ МОВОЮ: ВПЛИВ НА ПРОЦЕС НАВЧАННЯ І ВИКЛАДАННЯ}

У статті розкрито чинники, щуо впливають на процес оцінювання навиків та умінь володіння іноземними мовами. Проаналізовано види очінювання з використанням IКТ. Представлено досвід проведення оцінювання навиків письмової і усної мови студентів із застосуванням мовного портфоліо, цифрового оповідання (розповіді) в практиці навчання іноземним мовам. Описані приклади студентських мовних портфоліо; доведено дочільність його використання у навчальному процесі у вищих педагогічних навчальних закладах.

Ключові слова: оцінювання, метод оцінювання $і$ інструменти, цчифрова розповідь, мовне портфоліо, досягнення у навчанні мови, вищий педагогічний навчальний заклад.

Самойленко Наталия Борисовна,

Севастопольский государственный университет, г. Севастополь

\section{ОЦЕНИВАНИЕ ВЛАДЕНИЯ ЯЗЫКОМ: ВЛИЯНИЕ НА ПРОЦЕСС ПРЕПОДАВАНИЯ И ОБУЧЕНИЯ}

В статье исследованы факторы, влияюшие на прочесс оченивания навыков и умений владения иностранными языками. Проанализировань виды оценивания с использованием ИКТ. Представлен опыт проведения оценивания навыков письменной и устной речи студентов с применением языкового портфолио, ичфрового повествования (рассказа) в практике обучения иностранньлм языкам. Описаны примеры студенческих языковых портфолио; доказана иелесообразность его использования в учебном процессе в высших педагогических учебных заведениях.

Ключевые слова: оченивание, метод оценивания и инструменты, ичифровой рассказ, языковое портфолио, достижения в обучении языку, высшее педагогическое учебное заведение.

Introduction. The last researches are devoted to a practice-based exploration of technology in assessing English language teaching (ELT) and changes that have taken place in the area of assessment. The scientists hold the view that for making language learners better communicators and 'users' of the language it is necessary to develop the ability to communicate and do things with language [5, p. 147].

In our view we need global and specific students' skills to focus on assessing [6]. We agree that assessment provides opportunities for learning, motivation, self- reflection [5, p. 39].

We need to consider the influence of the importance of autonomous learning, based around tasks and real situations, the selfreflection and peer reflection role, the issue of motivation for effectively assessing in the 21 st Century language class.

The Partnership for 21st Century Skills was established by the National Education Association (NEA) in 2002 and the "Framework for 21st Century Learning" was developed. Among 18 skills as essential themes for learning in the 21st century "Four Cs" (Critical Thinking, Communication, Collaboration, Creativity) and Innovation were highlighted [4].

In 2017 a comprehensive descriptive scheme of language proficiency and a set of common reference levels (A1-C2) defined in illustrative descriptor scales, plus options for curriculum design promoting plurilingual and intercultural education was presented by the Common European Framework of Reference for Languages: Learning, teaching, assessment (CEFR). It was highlighted the aims of language learning [3].

The development of language competences is essential for social inclusion, mutual understanding and professional development. The CEFR has contributed to the implementation of the Council of Europe's language education principles, including the promotion of reflective learning and learner autonomy [4].

Problem statement. At present our graduates lack employability skills such as problem-solving, decision-making and teamwork. The revision of education system is necessary in order to prepare graduates for the 21 st century. Some teachers prefer the traditional way of teaching instead of exploring new ways of teaching for creating a learner-centered and interactive environment [1]. In our ESL classes the students don't remain passive and often express their opinions. We "foster an effective environment with proper methods on how students can be more independent in the class so they can be more motivated and engaged in their learning" [2, p. 3]. 
Nowdays there are changes in the formative assessment. While our educational process we not only assess students at different stages and provide feedback, but help them into their future learning. It is obvious that assessment is part of the learning process, because the students can improve their results. But they need to take the information from assessments.

Despite the teacher's mark is more for the students, the teachers spend additional time and energy on formative assessments, and we mention some benefits of formative assessments. We agree that well designed formative assessments with useful, and well thought feedback, will greatly help both students and understanding of their progress. From our own experience we believe teachers in the EL classroom have the impact. One of them is the washback (backwash) [5, p. 157].

The washback (backwash) effect is the impact that an assessment have on the teaching and learning. The scholars point out the role of good assessments for real learning opportunities if the assessments the students are given are defined, not focus only on accuracy and are not time limited, reflect good practices in language learning. Such assessments have a positive washback not only from the teaching perspective but the learning perspective [5].

One of the most popular now form of evaluation is peer evaluation/self evaluation. In comparison with the previous process organizing classroom assessments, offered by Davison and Leung (2009): planning assessments; collecting information on student learning through the assessment; making judgements about performance and providing appropriate feedback, today students' selfevaluating and building up a picture of their own learning have become more important [5].

We believe the key goals of assessment are to make students better, independent, more motivated learners, to be aware of their own shortfalls and strengths in learning. Reflection, peer evaluation, self-evaluation and self-assessment help teachers and students.

In our practice we use European Language Portfolio (ELP) and the e-portfolio like a digital version of a portfolio. It makes a real contribution because it includes video, audio recordings, chat room discussions, forum and other electronic artifacts [8].

Research questions. European Language Portfolio (ELP) is an approach that presents learners with a situation that requires them to evaluate their skills in which the major goal is for learners to produce outputs. In the context of English language learning, the students find learning via ELP is more authentic and meaningful that helps them to be more engaged in learning the language and evaluating their language skills. This method can help students to develop their higher order thinking skills [8].

Methodology. The aim of the study is to clarify the implementation of ELP in English language learning process has positive response on students' English language skills. 25 undergraduate students of 22-25 years old from the Sevastopol State University for 2015-2017 years were involved in this study. We conducted a research for presenting the results of our students' self-assessment in the ELP in English language class. The group of the students in a higher educational institution improved their abilities in different skills in their autonomous learning.

Findings. The learners of 22-25 years record their language learning and cultural experiences at educational institutions and or outside educational institutions. The personal document of a learner that has three parts [7]:

- a language passport - for summarizing students' linguistic and cultural identity, language qualifications, experience of different languages and contacts with different cultures using;

- a language biography - for setting learning targets, reflecting on experiences in language learning and on intercultural communication and student's progress assessing;

- a dossier - for keeping samples of students' work in the language(s) they have learnt or are learning.

Common European Framework of Reference for Languages defines six levels of communicative proficiency, which are summarized for the five skills of listening, reading, spoken interaction, spoken production and writing. The students were required to evaluate their skills. The instrument was an evaluation rubric adapted from an existing set of criteria developed by the Common European Framework of Reference for Languages [4].

In the language passport the students summarize their linguistic and cultural experience [5, 7].

The 'Self-evaluate your language skills' scheme (diagr. 1) helps the students to assess their level of proficiency in the languages they know according to six reference levels defined within the (CEFR). The scale of reference is used in certification by national language education system, by employers [8].

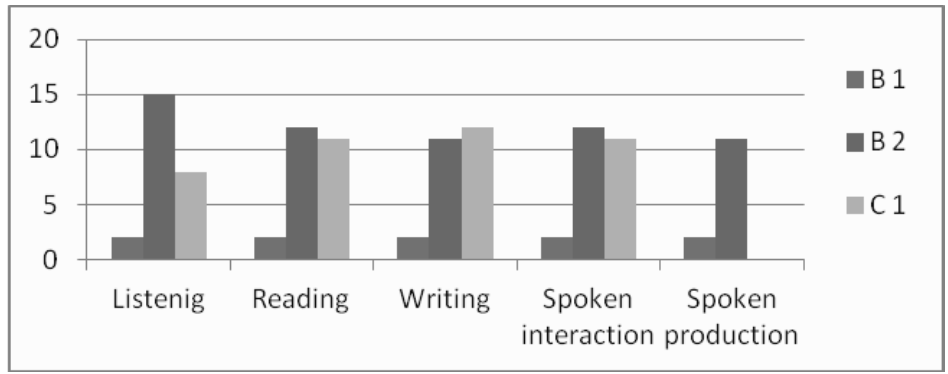

\section{Diagram 1. 'Self-evaluation language skills' results}

Students present the lists of their Certificates and diplomas: Secondary Education Certificate, External Independent Testing (Ukrainian Center for Educational Quality Assessment); Bachelor Degree in English Language and Foreign Literature; Cambridge English Level 2 Certificate in ESOL International (Advanced); TKT Modules 1, 2, 3 (Cambridge English Language Assessment Part of the University of Cambridge).

Summarised their linguistic and intercultural experience we can mention they use languages for studying or training, living or travelling abroad, mediating between languages.

The language biography helps the students to set learning targets, to record and reflect on language learning and on intercultural experiences and regularly assess progress. The templates of the Language Biography focus on goal setting. 
It helps them in their current language learning situation, whether in formal classes or workshops or during travel abroad for business, academic credit, or pleasure [7]. Its secondary purpose is to help them become a lifelong learner so that they can learn new languages and become culturally competent in new cultural environments wherever they find them after their formal language learning ends.

Here are some examples from students' reflections on which activities work best for the students as a language learner:

1) Listening: language lab assignments / CD ROM to accompany textbooks, listening to songs and obtain copies of the words, watching foreign films / foreign TV shows, international broadcasts.

2) Reading: Internet assignments and follow-up class discussions, research for reports and presentations, group projects with reading required for all participants, write down words and idioms that I want to learn, summarize the content of important text, seek out reading materials related to my professional and personal interests.

3) Writing: individual research projects and reports, pre-writing activities, peer editing before final draft, teacher feedback with option of writing second draft, researching books and articles, including those found online, and taking notes in order to plan a writing assignment, making an outline and preparing key vocabulary before writing, composing lists of mistakes and correcting them, entering and participating in internet chatrooms, taking articles from magazines or internet sites and grouping words by themes for topics, selecting, memorizing and using vocabulary for assigned topics and for topics in professional and personal areas of interest, identifying opportunities to e-mail native speakers in professional and personal areas of interest.

4) Spoken production: listening to and redoing presentations that are recorded earlier, planning for questions and answers from the audience, speaking and recording words and sentences and comparing them with the original audio files that are listened to, memorizing short texts and presenting them to a friend who helps with cues, prompts, and pronunciations, composing lists of mistakes and correcting them, feedback through the teacher and through peers, using special software for personal goals in language learning..

Spoken Interaction / person to person: seeking answers to questions about how to use new vocabulary and grammar, going beyond the minimum to learn about cultural or professional areas that will help me interact with native speakers later on, engaging in activities to improve pronunciation in order to communicate more easily with native speakers, memorizing phrases that I know I will need to use with others, grouping words and phrases for common topics: sports, politics, music, testing new vocabulary, practice speaking with native speakers and language experts.

We discovered the students' goal settings by the results of their common self-assessments. We present the frequently mentioned students' goals settings

1) Listening goal settings: understand standard spoken language in everyday situations (in a noisy setting where several people are talking, public announcements in a train station, at a sporting event).

2) Reading goal settings: understand and interpret virtually literary or non-literary written text (abstract, structurally complex, highly colloquial).

3) Spoken Interaction / Person to Person goal settings: participate in conversations without stopping to search for the necessary words or expressions, making allusions and at times incorporating humor, converse with any native speaker on specialized, abstract or complex topics outside my areas of expertise.

4) Spoken Production goal settings: make an announcement with ease, using stress and intonation to convey finer shades of meaning appropriate to the context; reformulate ideas with great flexibility to emphasize or clarify a point of view.

5) Writing goal settings: express clearly, tailoring writing to the intended audience; elaborate case effectively and accurately in complex formal letters (addressing or making complaints, responding to situations requiring tact and delicacy).

In the language dossier the students of the Master Course syllabus "Philology" - "Foreign languages and intercultural communication", "English language and the foreign literature" demonstrated their skills (the samples of their works in the language(s) they have learnt or are learning).

6) Reading/ Books: "Fahrenheit 451" by Ray Bradbury, "Catalina" by Somerset Maugham, "And there were none" by Agatha Christie, "Never let me go" by Kazuo Ishiguro, „The Chinese study” by T. Campbell, "How to Raise a Healthy Child in Spite of Your Doctor" by Robert S. Mendelsohn, "Jonathan Livingston Seagull” by R. Bach.

7) Writing: a summary of research papers, abstracts, Master thesis abstracts, articles in academic journals, conference abstracts; $\mathrm{CV}$, bio data, personal profile, grant proposal, glossary for research paper.

8) Spoken production: presentation prepared in advance; digital story.

9) Listening: Songs: Post Malone -“Rockstar", Kokab -"Got U”, James Blunt-“Goodbye my lover", Passanger -"Let her go", Ellie Goulding - "Burn", Glenn Morrison feat. Islov -"Goodbye", Imagine Dragons -"Believer".

10) Video, audio files: digital story "Mind game", presentations: "Does human behavior change?", "My teaching practice experience at University".

Cultural awareness is also a crucial 21st century skill. Being aware of other cultures and how they influence what people say, do or write is a key factor of critical literacy. The students assign a score for their dominant culture and one target culture.

The European Language Portfolio is for learners, teachers, teacher trainers, decision makers and employers. There are some benefits. The learner monitors and evaluates his/her own learning; encourages lifelong learning of languages. The teacher shares responsibility for the learning process, promotes autonomous learning; provides and observes practical evidence of second/foreign language communicative proficiency and intercultural experience [8].

Hence our focus in this research is on the use of ICT to provide formative assessments. Now days technology has an impact on language assessment and provides new ways of assessing: video the students interacting in groups or working on a monologue or story; get students to record podcasts and audio files, to develop their written work in blogs and wikis [8, p. 162]. There is an abundance of tools that can be used in assessment. From our experience we suggest for analyzing ELT assessment mode and tools (table 1). 
ELTassessmentmodeandtools

Table 1

\begin{tabular}{|c|c|}
\hline Tools & How to use \\
\hline \multicolumn{2}{|l|}{ Writing } \\
\hline $\begin{array}{l}\text { Blogger } \\
\text { www.bloger.com }\end{array}$ & $\begin{array}{l}\text { Students keep diaries, write stories, reflect on classes, develop communities. Teachers and peers } \\
\text { leave comments. } \\
\text { www.teachertrainingvideos.com/newBlogger/index.html }\end{array}$ \\
\hline $\begin{array}{l}\text { Tricider } \\
\text { https://tricider.com/en/t/ }\end{array}$ & $\begin{array}{l}\text { Quick and simple discussion board, adding ideas, pictures, video and links around a given theme, } \\
\text { commenting on the peers' ideas; } \\
\text { For brainstorming, debates, essay preparation and drafting. } \\
\text { www.teachertrainingvideos.com/tricider/index.html }\end{array}$ \\
\hline $\begin{array}{l}\text { Wallwisher } \\
\text { http://wallwisher.com/ }\end{array}$ & $\begin{array}{l}\text { Provides a sort of collaborative electronic board for brainstorming, preparing essays and projects, } \\
\text { and sharing ideas. } \\
\text { www.teachertrainingvideos.com/wall/index.html }\end{array}$ \\
\hline \multicolumn{2}{|l|}{ Reading content } \\
\hline $\begin{array}{l}\text { Breakingnewenglish } \\
\text { www.breakingnewsenglish. } \\
\text { com/ }\end{array}$ & $\begin{array}{l}\text { Useful website of reading and listening content, related to recent news events. Includes lesson plans } \\
\text { around the content; for assessments. }\end{array}$ \\
\hline $\begin{array}{l}\text { Listenaminute } \\
\text { http://listenaminute.com/ }\end{array}$ & Source of reading and listening content adapted for assessments. \\
\hline \multicolumn{2}{|l|}{ Listening material } \\
\hline $\begin{array}{l}\text { ELLLO English } \\
\text { http://elllo.org/ }\end{array}$ & $\begin{array}{l}\text { Collection of monologues and dialogues from a whole variety of speakers which can be used for } \\
\text { assessment purposes. }\end{array}$ \\
\hline \multicolumn{2}{|l|}{ Audio/speaking } \\
\hline $\begin{array}{l}\text { Vocaroo } \\
\text { http://vocaroo.com/ }\end{array}$ & $\begin{array}{l}\text { Audio tool for recordings and sharing via email, embedded in a blog, wiki or virtual learning } \\
\text { environment or downloaded. } \\
\text { www.teachertrainingvideos.com/vocarool/index.html }\end{array}$ \\
\hline $\begin{array}{l}\text { VoiceThread } \\
\text { http://voicethread.com/ }\end{array}$ & $\begin{array}{l}\text { Excellent tool used collaboratively; adding written or audio comments concerning an image, video } \\
\text { or document. } \\
\text { www.teachertrainingvideos.com/voiceThread/index.html }\end{array}$ \\
\hline $\begin{array}{l}\text { MailVu } \\
\text { http://mailvu.com/ }\end{array}$ & $\begin{array}{l}\text { Simple audio tool simple webcam recordings in pairs or groups; for pair work assessments. } \\
\text { www.teachertrainingvideos.com/mailVu/index.html }\end{array}$ \\
\hline $\begin{array}{l}\text { Voxopop } \\
\text { www.voxopop.com/ }\end{array}$ & $\begin{array}{l}\text { Audio tool works like a discussion board but with recordings for setting up questions, oral answers, } \\
\text { replies and comments. Useful for oral work, discussions, brainstorming, opinions. } \\
\text { www.teachertrainingvideos.com/voxopop/index.html }\end{array}$ \\
\hline \multicolumn{2}{|l|}{ Virtual learning environments } \\
\hline $\begin{array}{l}\text { Moodle } \\
\text { https://moodle.org/ }\end{array}$ & $\begin{array}{l}\text { Online virtual learning environment used for writing and feedback with chat rooms, forums for } \\
\text { assessment aims; creating online quizzes and tests to evaluate students' progress. }\end{array}$ \\
\hline $\begin{array}{l}\text { Edmodo } \\
\text { www.edmodo.com/ }\end{array}$ & $\begin{array}{l}\text { Free online virtual learning environment for sharing, discussions and brainstorming, uploading of } \\
\text { assignments and drafts, feedback. } \\
\text { www.teachertrainingvideos.com/edmodo1/index.html }\end{array}$ \\
\hline \multicolumn{2}{|l|}{ Quizmaking } \\
\hline $\begin{array}{l}\text { Pro-Profs } \\
\text { www.proprofs.com/quiz- } \\
\text { school/ }\end{array}$ & Free online quiz maker for formative and periodic assessments. \\
\hline
\end{tabular}

We provide a series of mini case studies. For example, the teacher is focusing on writing. The objective is to make the students more fluent in their writing and to get them to focus on the process of writing, as well as the end product [1]. Various activities are set up in the class to support this, including the students using digital story after their ELT classes.

One of the interactive forms is traditional oral narration, which is presented in digital form. It is Digital Storytelling (DS) [2]. The are some benefits: for students of different learning styles; a small-form media product with online visual, imaginary, musical and verbal digital tools.

Conclusion. In conclusion we can say that assessment has changed because the skills and content of any modern language course, the nature of assessment, the impact of technology have changed. With the help of technology we can assess the students' ability for participating in a pair work oral activity; planning and organizing the article for a specific genre. As part of the assessment, the students are asked to do their own digital stories.

We used LP for supporting our students' thinking about their language learning; helping them to understand the central aim of language learning; teaching them how to assess themselves; increasing the learners' motivation; using European standards of proficiency (the CECR levels).

The findings showed that the revision of education system is necessary in order to prepare graduates for the 21 st century. In our view we need global and specific students' skills to focus on learning process. We agree that all modern changes provide opportunities for learning, motivation, self- reflection and developing students' employability skills. 


\section{References:}

1. Самойленко Н.Б. Developing Academic writing in intercultural university settings: key features, efficiency and challenges / Н.Б. Самойленко // Наукові записки Національного університету «Острозька академія». Серія «Філологічна» : збірник наукових праць / укладачі : І. В. Ковальчук, О. Ю. Костюк, Л. М. Коцюк. - Острог : Видавництво Національного університету «Острозька академія», 2016. - Вип. 60. - 330 с. - С. 7 - 10 .

2. Barseghian T. What's The Value of Digital Storytelling / T. Barseghian // Mind Shift. 2011. [Electronic Resource] - Mode of access: http://ww2.kqed.org mindshift/2011/01/21/whats-the-value-of-digital storytelling (accessed 22 February 2018).

3. CEFR Companion volume with New Descriptors [Electronic Resource] - Mode of access: https://www.coe.int (accessed 22 February 2018).

4. Connecting the $4 \mathrm{Cs}$ of 21st Century Education (With a 5th C!) [Electronic Resource] - Mode of access: https://www. Power school. com/resources/ blog/ connecting-4-cs-21st-century-education-5th-c/ (accessed 19 February 2018).

5. Innovations in learning technologies for English language teaching/ Gary Motteram// British Council 2013, Brand and Design/ C60710 Spring Gardens London SW1A 2BN, UK.- 201 p. (www.britishcouncil.org)

6. Jenkins J. Global Englishes. A resource book for students/ J. Jenkins - Abingdon, GB: Routledge, 3rd edition, 2015. - 288 p.

7. The University of Southampton - Mode of access: https://www.southampton. ac.uk/ml/ about/ staff/ wmlb.page. (accessed 18 February 2018).

8. Understanding languages : learning and teaching - Mode of access: https://www.futurelearn.com/courses/understanding-language/0/ steps/21196. (accessed 27 February 2018). 